\title{
Study Country
}

National Cancer Institute

\section{Source}

National Cancer Institute. Study Country. NCI Thesaurus. Code C153134.

A country in which a study takes or took place. 